\title{
Automatic Generation of Template Images for Detecting Vehicles in Parking Lots
}

\author{
Kazumasa Iwasa Non-member (Meijo University) \\ Toshimitsu Tanaka Non-member (Meijo University) \\ Yuji Sagawa Member (Meijo University) \\ Noboru Sugie Non-member (Meijo University)
}

Keywords : image processing, detection of parking vehicles, template image

Traffic jam in and around parking lots will be reduced, if positions of open area are informed to drivers waiting at entrances of them. Therefore to detect cars in outdoor parking lots, several methods using the image processing have been proposed. One of them is a method which judges visibility of white lines.

White lines are drawn in almost all parking lots to separate each parking division. If a car stops in a parking division, the car hides the white lines which is around the division and far from the camera. Thus the method was developed which judges car parking by detecting the hiding. In experimental results, the method has achieved high detection accuracy of about $98 \%$.

The method needs one template image for each camera. Since the images were created by human in the previous research, much cost and time was required for their creation. In this paper, we present the method automatically generating the template images.

Firstly our method emphasizes input images by expanding their

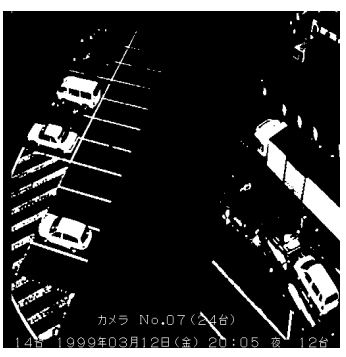

(a)Not emphasized

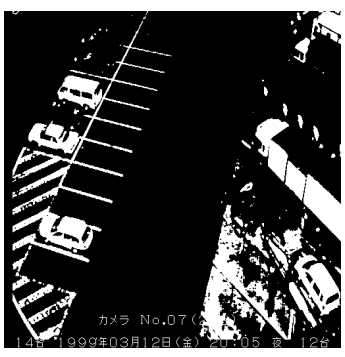

(b) Emphasized

Fig. 1. Expansion of intensity

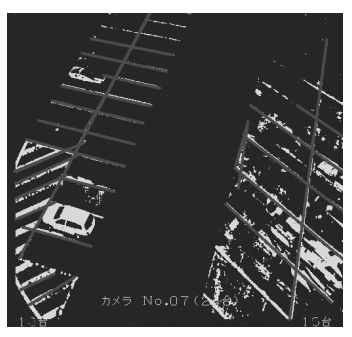

Fig. 2. Detected white lines

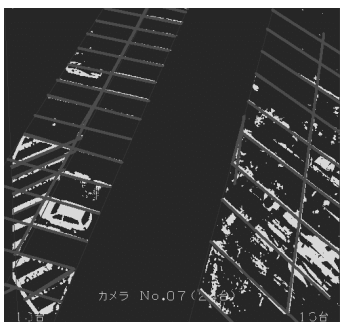

Fig. 3. Completed white lines intensity, then converts them to binary images. Effect of the intensity expansion is shown in Fig.1. Much white lines are correctly detected from the emphasized image. From several of the images, our method synthesizes an image in which few car appear. One example is shown in Fig2.

Secondly white lines are detected by using the Hough transform. Then the lines that are roughly parallel to each other on the image are gathered in a group. If the lines are parallel in the three dimensional space, the lines are cross at a vanishing point on the image. Thus the most probable crosspoint of the lines is computed, then the lines far from the point are removed from the group.

Since some of white lines are not correctly detected, the method completes white lines by the rule that the white lines on the parking lots are parallel and same length. Figure 3 is the completed image of Fig.2. In Fig.2 some white lines on the right side of the image do not appear, however, they are correctly displayed in Fig.3.

Finally, each rectangle area, three sides of which are surrounded by the white lines, is selected as a parking division. One of the three white lines is associated to the parking division, if the line is expected to be hidden by a car stopping at the division. The information is saved in the template image as shown in Fig.4.

In experimental results, the accuracy of car detection with automatically generated templates was $96 \%$. The rate is sufficiently high although it is a little lower in comparison of the manually created templates. By using the proposed method, the cost for supplying one template image was reduced from 1-2 hours to a few minutes.

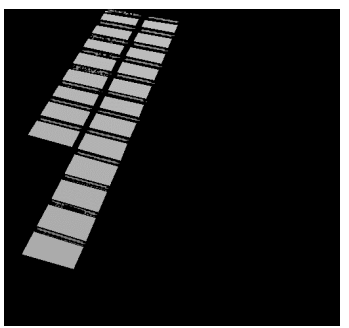

Fig. 4. Generated template image 


\title{
論 文
}

駐車車両検出のためのテンプレート画像の自動作成

\author{
非会員 岩佐 和真* 非会員 田中 敏光* \\ 正員 佐川 雄二* 非会員 杉江 昇*
}

\author{
Automatic Generation of Template Images for Detecting Vehicles in Parking Lots \\ Kazumasa Iwasa*, Non-member, Toshimitsu Tanaka*, Non-member, Yuji Sagawa*, Member, Noboru Sugie*, Non-member
}

\begin{abstract}
An increase in the number of parking lots is very slow though that of cars increases much every year. Thus, efficient management of parking lots is needed. If information of vacant divisions is transmitted to cars waiting at gates of parking lots, traffic jam caused by cars searching parking divisions will be decreased. Therefore several methods for detecting parking cars have been developed. Especially, the method that detects cars hiding white lines drawn on parking lots is highly reliable. The method needs a template image for each camera. Since these images were created by human in the previous research, much cost and time was needed.

In this paper, we present the method automatically generating the template images. Firstly, our method synthesizes an image of parking lots including no cars from several images. Then, the method detects white line segments from the image. The line segments are corrected in consideration of the rule that white lines on the parking lots are parallel and their length is constant. Finally, parking divisions are determined from the line segments and stored in the template image. In the experiment using the template generated by our method, accuracy of detecting cars was about $96 \%$. The template is comparable to the manually created template in accuracy.
\end{abstract}

キーワード：画像処理, 駐車判定, テンプレート画像

Keywords : image processing, detection of parking vehicles, template image

\section{1. はじめに}

全国の四輪車保有台数は, 2005 年 9 月末時点で約 7571 万 台に達しており (2), 年々増加している。しかし, 駐車場の増 加はそれに追いついていないので, 慢性的に駐車困難な状 況となっている。この結果, 休日の繁華街やレジャー施設 などでは, 空いている駐車場所を探して移動する車が交通 量を増やしたり，駐車待ちの車列が道路にあふれて交通渋 滞を引き起こしたりしている。この問題を解決するには, 駐車場の状況を検知して車を空き区画に効率的に誘導する ことが必要で, $\mathrm{ITS}^{(1)}$ の一分野として研究が行われている。

駐車車両を認識する手法の 1 つに，固定カメラで撮影し た画像を処理して区画ごとに駐車の有無を調べる方法があ る。1 台のカメラで多くの区画をカバーできるため, 駐車区 画ごとにセンサーを設置する方式に比べてコストを下げる ことができる。また，すでに設置してある監視カメラの画 像を利用することもできる。このため, 郊外の大規模な露

$*$ 名城大学理工学部情報工学科

T468-8502 愛知県名古屋市天白区塩釜口 1-501

Department of Information Engineering, Faculty of Science and Technology, Meijo University,

1-501 Shiogamaguchi, Tenpaku-ku, Nagoya 468-8502
天駐車場に適している。 画像中の駐車車両の検出には，車両の追跡などによって 駐車区画にとらわれずに車両を検知する方法(3)や, 全区画が 空車のときの画像を参照して正規化成分特徵量から判定す

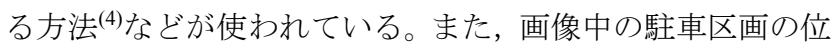
置を指定するテンプレート画像を用いて, 車両のパーツご とに領域を見つけ駐車を認識する手法 ${ }^{(5)}$ や, 駐車区画ごとに エッジ画素の割合を調べる事で車両の有無を判定する手法 ${ }^{(6)}$ もある。

ただし，1 台のカメラが担当する範囲が広くなると，斜め から撮影される車両が多くなるため, 車高の高い車は隣接 する駐車区画にはみ出して写ってしまう。特に画像の周辺 の駐車区画では, はみ出す範囲が広くなるため, 誤判定が 増加する。この問題を解決すために複雑な計算を行う手法 ${ }^{(7)}$ もあるが，精度はさほど向上していない。

そこで, 車両がはみ出して写ることを逆手にとって, 車 両が駐車区画を区切る白線を隠すことを検出して, 駐車を 判定する手法 ${ }^{(8)}$ が提案されている (駐車の判定方法は 2 章で 述べる)。実験では, 晴れの日で約 98\%の高い認識率を達成 している。 
この手法はテンプレート画像を使って駐車を判定する。 テンプレート画像には, 駐車領域とそこに停まった車が遮 蔽する白線領域とが, 対応付けられて記録されている。テ ンプレート画像は 1 台のカメラに付き 1 枚あればよいが, 新しく車両判定システムを導入する, カメラの配置を変え る, 白線を引き直すなどの変更があると, そのつど作り直 す必要がある。また, 長期間の運用では, タイヤとの摩擦 で白線が削られるため, 定期的にテンプレート画像を更新 する必要がある。

先行研究 ${ }^{(8)}$ では, ペイントツールなどを使って, 手作業で テンプレート画像を作成していたため, 作成に 1 枚当たり 1 〜2 時間かかっていた。そこで本研究では，この手間を軽減 するため, 車両認識に使うカメラで撮影した画像からテン プレート画像を自動作成するシステムを作成する。

2 章では先行研究 ${ }^{(8)}$ の車両検出手法の概要を述べる。テン プレート自動作成手順は 3 章から 6 章に示す。 7 章では, 自 動生成したテンプレート画像を使って駐車車両の認識率を 評価する。

\section{2. 白線の遮蔽を利用した駐車判定 ${ }^{(8)}$}

あらかじめ，カメラごとに，駐車領域と白線領域を記録 したテンプレート画像を作成しておく。図 1(a)は固定監視力 メラの画像で, 図 1(b)はそのテンプレート画像（ただし，小 型車の駐車区画のみ定義）である。このテンプレート画像 は先行研究で用いたもので, 手作業で作成されている。図 1(c)はその一部を拡大したもので, 四角形が駐車領域, 細い 線が白線領域である。

駐車領域には，それぞれに異なる整数值を ID として与え る。また，ある駐車領域に停まった車両が隠すと予想され る白線領域には, その駐車領域の ID から一定值（画像中の 駐車区画数より大きな值）を引いた值を ID として与える。 領域の ID はそこに含まれる画素の值としてテンプレート画

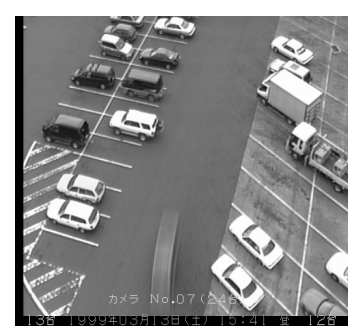

(a) Input image

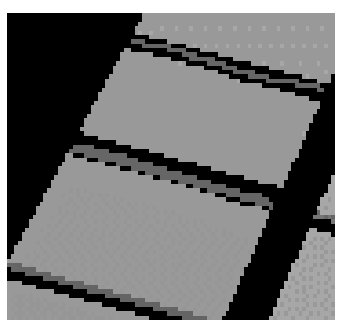

(c) Close-up of (b)

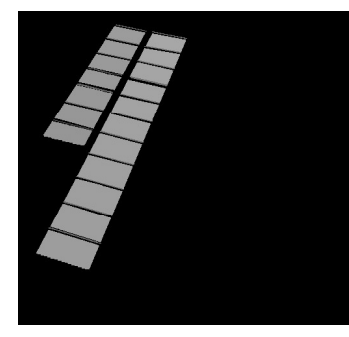

(b) Template image for (a)

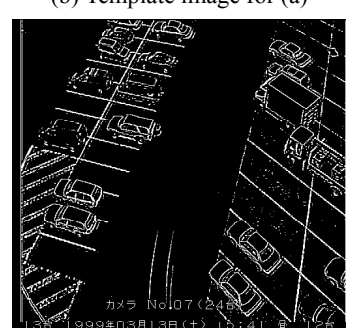

(d) Edge image of (a)
図 1 テンプレート画像とエッジ画像の例

Fig. 1. A sample of the template image and the edge image.
像に記録する。このようにして, 駐車領域と白線領域を対 灾付けている。

判定処理では, まず, カメラから入力した画像を濃淡変 換したのち, $\log$ 変換で輝度を補正する。次に, ラプラシア ンIIオペレータでエッジを抽出し, 固定閾值で 2 值化する。 この手順で図 1(a)を処理すると図1(d)となる。この画像には 車両のエッジと白線のエッジの両方が含まれている。

白線領域のそれぞれで, エッジ画像に現れる白画素（エ ッジ点）の割合を求める。この值が閾值より小さければ, 白線が隠されていると考えて, ID 番号から対応する駐車区 画を見つけ，そこに車両があると判定する。ただし，車両 があっても白線が隠されないことがあるので, 駐車と判定 できない場合には，駐車区画ごとにエッジ点の割合を求め, この值が闇值以上ならその区画に車両があると判定する。

\section{3. 空車画像の作成}

駐車場に車両が 1 台も停まっていない状態の画像を空車 画像と名づける。テンプレート画像はこの空車画像を 2 值 化した画像から作成する。

休業時間のある駐車場では空車画像を撮影することがで きるが，高速道路のパーキングエリアのように 24 時間運用 している場所では, 空車画像が撮影できるとは限らない。 そこで, 時間をおいて撮影した複数枚の画像（ただし，駐 車車両は少ない) を統計処理して，2 值化された空車画像を 合成する。以下にその手順を述べる。

〈3-1〉 濃度值の伸張化 判別分析法は画像の 2 值化 でよく使われる手法であるが，これだけでは白線を正しく 検出できない。図 2 に昼間と夜間の画像を判別分析法で 2 值化した例を示す。図 $2(\mathrm{~d})$ に示す夜間の 2 值化画像では, 上 部の白線が途切れたり消えたりしている。

サービスエリアなどの屋外駐車場では, 多くの場合, 監

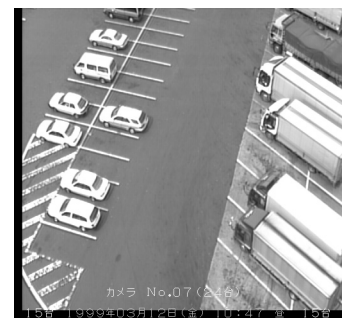

(a) Daytime

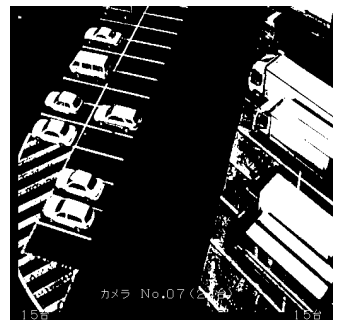

(c) Binary image of (a)

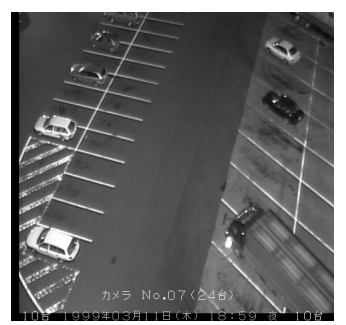

(b) Nighttime

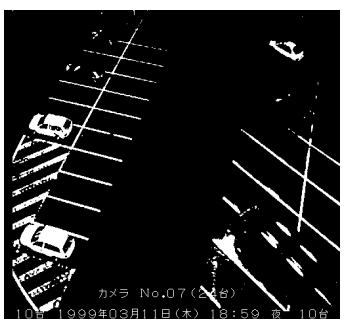

(d) Binary image of (b)
図 2 昼夜の駐車場画像を 2 值化処理した結果

Fig. 2. Binary images of a parking lot in daytime and nighttime. 


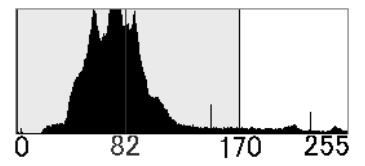

(a) Histogram before the

intensity expansion

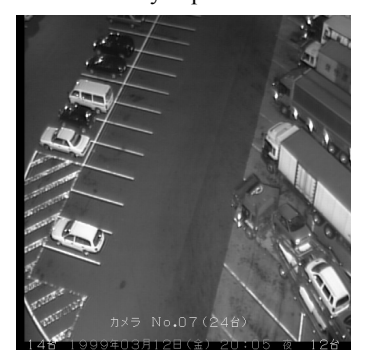

(c) Grayscale image before the expansion

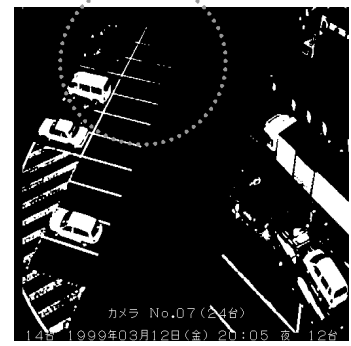

(e) Binary image of (c)

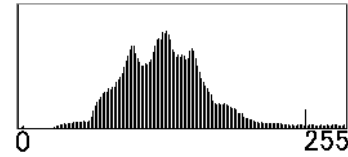

(b) Histogram after the intensity expansion

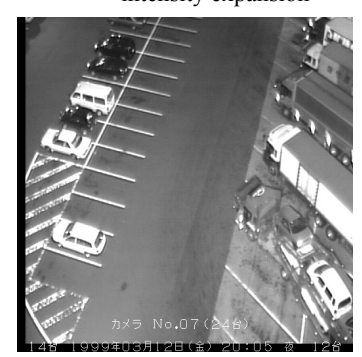

(d) Grayscale image after the expansion

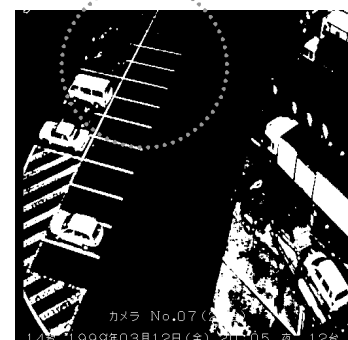

(f) Binary image of (d)

困 3 ヒストグラム伸張による輝度範囲の拡大

Fig. 3. Expansion of intensity.

視カメラは照明塔に併設されている。このため, 夜間はカ メラから遠くなるほど照明が暗くなってしまう。そこで, ヒストグラムを伸張して白線を強調する。

具体的には, 式( 1 )により, 濃度值 $a \sim b$ の範囲を線形に 0 〜255 に引き延ばす。また, 濃度值 0 〜 $a$ を 0 に, $b$ 〜 255 を 255 に変換する。

$$
Z^{\prime}= \begin{cases}0 & (0 \leq Z<a) \\ 255 \times \frac{Z-a}{b-a} & (a \leq Z \leq b) \\ 255 & (b<Z \leq 255)\end{cases}
$$

$a$ と $b$ は, 濃度值の平均 $E$ と標準偏差 $\sigma$ から式 $(2)$ にり 決定している。これは濃度值の頻度が高い部分を伸張する ことを意味している。

$$
\left.\begin{array}{l}
a=\max (E-2 \sigma, 0) \\
b=\min (E+2 \sigma, 255)
\end{array}\right\}
$$

この手法でヒストグラムを伸張化した例を，図 3 に示す。 この例では, 図 3(a)で 82 と示された位置が濃度值の平均で, 0 170 が伸張範囲となる。伸張化により濃度分布が図 3(b) のように引き伸ばされる。ただし，濃度值は整数に限られ るため, 伸張化後は值が飛び飛びになっている。

図 3(c) と (d)に伸張化処理による画像の変化を示す。夜間 は照明がしっかりと当たっている場所もあれば，そうでな い場所もある。図 3(c)の下部は比較的明るいが上部は暗い。

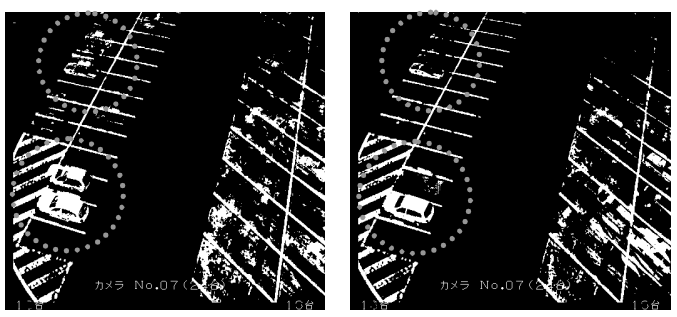

(a) Generated from 11 images

(b) Generated from 6 images

図 4 複数の画像から合成した空車画像

Fig. 4. Vacant images synthesized from several images.

このため, 図 3(c)を大津の閾值を使って 2 值化した図 3(e) では, 点線の円で囲まれた部分の白線が消えている。一方 図 3(d)では，どの場所の白線もはっきり確認できるので， 2 值化後の図 3(f)ではこの部分の白線も現れている。

それでも一部の白線は消えてしまうので, 5 章で述べる方 法で補完する。また，右側の大型車の区画では伸張化によ りノイズが増えている。これは, この部分の路面が周囲よ り明るいためである。後の章で白線検出の結果を示すが, この程度のノイズは白線検出の邪魔にはならない。

〈3·2〉 統計処理による空車画像の作成パーキング エリアではある程度時間が経過すれば車両が入れ替わる。 また, 深夜や早朝は比較的駐車車両が少ない。このため, 時間帯を選ぶことで，駐車台数が少ない画像を入手するこ とができる。撮影日が異なる画像を使えば，同じ場所に駐 車されている確率は低い。そこで, 本研究では, 時間をず らして撮影した複数の画像を統計的に処理して, 空車画像 を作成する。以下にそのアルゴリズムを示す。

(1) 複数の画像を取り込み, それらを前述の方法で 2 值化 画像にする。

(2) 全ての画素について, 次の処理を繰り返す。

・取り込んだ画像全てを比較し, 白と黒で出現頻度 の多い方を結果画像に書き込む。

図 4 に一例を示す。(a)は 11 枚の画像から作成した画像で, (b)は 11 枚の中から比較的駐車車両が少ない画像を人間が選 んで (この例では 6 枚), そこから作成した画像である。ど ちらの画像にも, 点線の円で囲まれた位置に車両が残って いるが，(b)のほうが台数は少ない。

図 4(b)で 2 台の車両が残ってしまったのは, 選択した 6 枚の画像の 3 枚以上に同じ車両が写っていためである。実 験に使った画像が同一日の限られた期間に撮影されたもの なのでこのような結果となったが，撮影期間を伸ばしたり， 別の日に撮影した画像を加えたりするなどの対策を取れば 解決できると考えている。

\section{4. 白線の検出}

3 章で作成した空車画像から, 次の手順で白線を求める。

$\langle 4 \cdot 1\rangle$ 直線の検出直線の検出には八フ変換 ${ }^{(9)}$ を用 いる。ただし，八フ変換では直線上の白画素の連続性は考 慮されないので, 途切れ途切れの点を結ぶ直線も検出され る。そこで, 八フ変換で検出された直線上に白画素の連続 


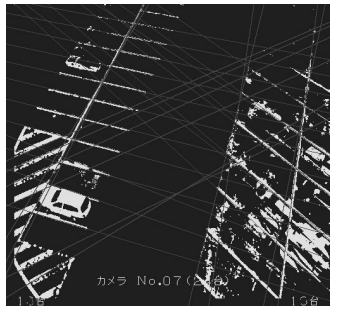

(a) Result image

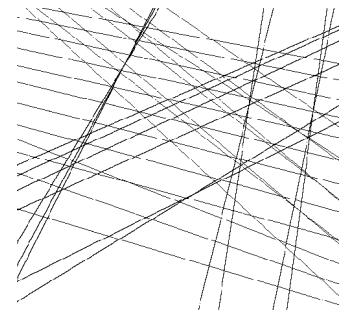

(b) Detected straight lines
図 5 直線の検出

Fig. 5. Detection of straight lines.

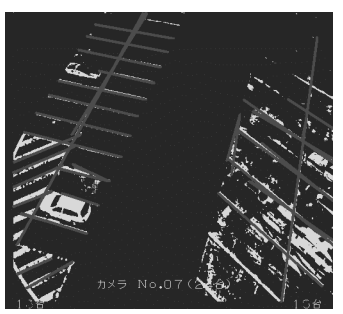

(a) Result image

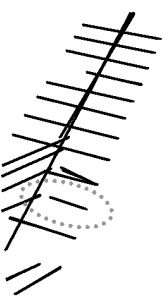

(b) Detected line segments
図 6 線分の検出

Fig. 6. Detection of line segments.

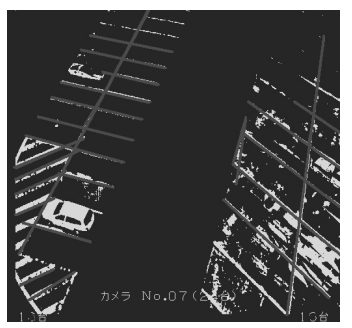

(a) Result image

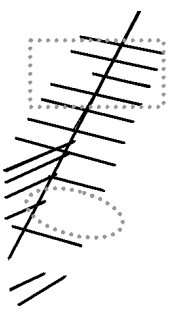

(b) Parallel line segments
図 7 平行線の検出

Fig. 7. Detection of parallel lines.

成分が存在しているかどうかを調べることで，白線を含む 直線か否かを判定する。以下にそのアルゴリズムを示す。

(1) ハフ変換により直線を検出する。

(2) 直線の傾き $\theta$ が $45^{\circ} \sim 135^{\circ}$ のを，（ $\theta$ は y 軸から反時 計回りに計った角度で, $\left[0^{\circ}, 180^{\circ}\right)$ で定義する）

$\mathrm{x}$ 軸方向に直線上で白画素が連続する数を調べ，そ の最大值を記録する。

それ以外の場合

$\mathrm{y}$ 軸方向に同様に調べ，最大值を記録する。

(3) 最大值が閾值以上の時, 正しい直線と判断する。

図 4(b)から直線を検出した結果を図 5(a)に示す。(b)は直線 だけを表示している。ほぼ白線と対応しているが，右側の 駐車領域では白線の端点を結ぶ直線も検出されている。

$\langle 4 \cdot 2\rangle$ 白線の検出 前節で検出された直線上で白点 が連続した区間を白線のエッジとして認識する。ただし， 白点が多少途切れた場合でも連続した領域として切り出す 必要があるので，以下の方法で白線の両端点を求める。

(1) 走査する方向を。直線の傾き $\theta$ の值が $45^{\circ} \sim 135^{\circ}$ のき
は $\mathrm{x}$ 軸方向に，それ以外は $\mathrm{y}$ 軸方向に選ぶ。

(2) 2 点間の距離 Lを 0 にリセットする。

(3) 直線上の白画素の組み合わせの全てについて, 以下の 処理を行う。

・ 2 点閒の距離が L 以上ならば,

(a) 2 点間に存在する全画素数と白画素数をそれぞれ 求め, 式( 3 )を用いて白画素の割合を計算する。

$($ 白画素の割合 $)=\frac{(2 \text { 点間の白画素の数 })}{(2 \text { 点閒の全画素数 })} \times 100 \cdots \cdots$

(b) 白画素の割合が $90 \%$ 以上ならば，この 2 点間の距 離をLに記録し，この 2 点の座標を保存する。

(4) 最終的に保持された 2 点を, 線分の始点と終点とする。

図 6(a)に線分の検出結果を示す。(b)は線分だけを表示し ている。図6(a)に示すように, ほぼ正しく, 直線から白線部 分を切り出すことができた。

直線上の白画素の数は, 最も多いものでも画像の高さに 相当する 500 個程度で, 多くは 100 個程度である。直線の 数も50 本以下である。このため, 直線上で白画素の全ての 組み合わせを調べても，たいした計算量にはならない。

〈4·3〉角度によるグループ化テンプレート画像を 作成するには，「検出された線分のどの組み合わせが 1 つの 駐車区画を形成しているか」を判定しなければならない。 一般に駐車区画は等間隔で一列に並んでいるため, 白線が 平行であることが境界線の特徵となる。そこで, 検出され た白線から, 平行線のグループを見つける。路面に平行線 を斜め方向から撮影した場合，透視投影により画像上では 平行線にならないが，直線の方向は近くなる。そこで, 方 向が近い直線をグループにまとめる。

〈4・4〉消失点を用いた平行線の検出 前節で求めた グループには, 誤検出された線分や偶然向きが近い線分も 含まれている。しかし, 平行線ならば, それらは画像上の 1 点（これを消失点と呼ぶ）で交わる。この性質を利用して 平行でない線分を除去する。以下にそのアルゴリズムを示 于。

(1) グループ内の線分の平均距離を求め, 閾值とする。

(2) 全ての 2 本の組み合わせに対し, 次の処理を行う。

(ア) 交点を求める。

(亿) 求めた交点と他の直線の距離を求め, それが閾值以 上となる直線の数を求める。

(3) (2)で求めた直線数が最小の交点を消失点に選ぶ。

(4) 選ばれた消失点と各直線との距離を求め, それが閾值 以上のとき，平行線でないとみなし削除する。

図 7 に平行線のみを選択した画像を示す。図 6 で検出さ れていた車のエッジに沿った線分（点線の楕円で囲んだ部 分）が除去されている。また, 図 6 の右側では, ノイズに より, 同じ位置に傾きがわずかに異なる線分が検出されて いるが, 図 7 では 1 本になっている。このように, 元の線 分に多少の誤差が含まれていても, 平行線を正しく判断す ることができた。 


\section{5. 白線の補完}

白線の中には，八フ変換で直線が検出できなかったため に失われたものや，空車画像のかすれなどによって長さが 足りないものがある。これらを次の方法で補完する。

〈5.1〉 白線の伸張 多くの駐車場では白線は駐車区 画の三辺にしか描かれていない。しかし，開いた部分では， 白線の端点（図 7(b)では平行で短い線分の端点）を結ぶ線が 駐車区画の境界となっている。これを予測境界線と呼ぶ。 以下の手順で, 平行線グループの端点から予測境界線を求 め，欠けた線分を補完する。

(1) 平行線グループに含まれる線分の全ての組み合わせに 対して，以下の処理を行う

(ア) 2 本の線分の端点を結ぶ直線の方程式を求める。

(亿) 求めた直線と他の線分の端点の距離を求め, それが 閾值以上の線分の本数を求める。

(2) 求めた線分数が最小の直線を予測境界線とする。

(3) 予測境界線と各線分の交点を求め, 線分長を補正する。

図 8(a)に線分長を補完した画像を示す。図 7(b)と図 8(b) を比べると, 点線の四角で囲まれた部分で白線が正しい長 さまで伸張されている。

〈5·2〉検出漏れ白線の補完 多くの駐車場では白線 は等間隔で平行に描かれているので，すでに検出されてい る線分同士の距離を求めることで, 検出漏れの白線を見つ けることができる。ただし, 空車画像は透視投影されてい るため, この処理を行うには元の路面の座標を復元する必 要がある。そこで,

(1) 平面射影変換 ${ }^{(10)}$ を用いて駐車場を真上から見た状態 を復元する。

(2) 平均間隔を求め未検出の直線の場所を予測する。

(3) 予測した直線の周辺で限定的にハフ変換を行い, 正し い白線の場所を求める。

手順で白線の検出漏れを補う。図 8(d)にこの方法で白線を 求めた例を示す。図 $8(\mathrm{~b})$ と(d)を比べると, 画像の上部や, 車両で隠れた部分の白線が補われている。

\section{6. テンプレート画像の作成}

〈6·1〉駐車領域の決定 1 つの駐車区画は長い白線, 予測境界線, 2 本の隣り合う短い白線で囲まれた領域にな る。そこで, 短い線分の端点と, 短い線分と長い線分の交 点の 4 つを頂点とする四辺形の内部を 1 つの駐車領域とす る。ただし, 風などで監視カメラが振動して白線のエッジ が駐車領域に入ってしまうことを避けるため, 四辺形の各 辺から 5 ピクセル内側を駐車領域に選ぶ。

検出された駐車領域ごとに ID 番号を付与する。ID は 150 から始めて, 連続した整数值を使う。テンプレート画像の 駐車領域の画素には, それぞれのID番号を書き込んでおく。

〈6·2〉白線領域の決定白線領域は, 白線のエッジ が写っているか否かを判定するための領域で，これまでの 処理で検出した線分の近傍にある。ただし, あとで駐車領

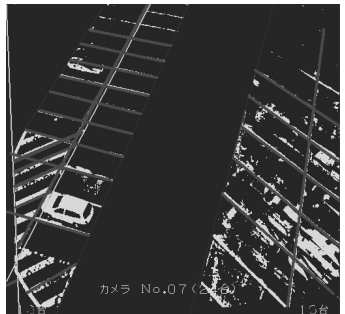

(a) Completing length of lines

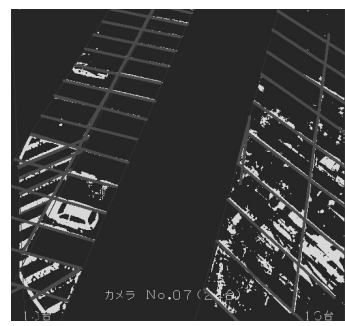

(c) Completing lost lines

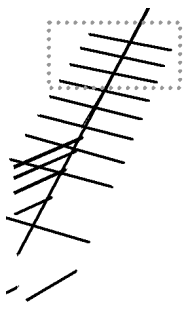

(b) Elongated line segments

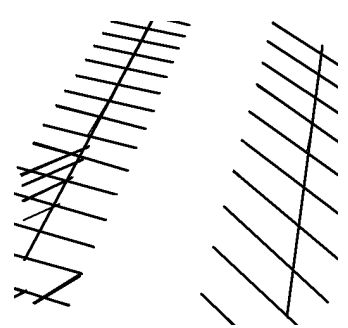

(d) Completed line segments
図 8 白線の補完

Fig. 8. Complement of white lines.

域と対応付ける必要があるので, 検出された線分のそれぞ れを, 駐車区画を求めるときに使った短い線分と長い線分 の交点で分割する。さらに，交点から 5 画素分短くする。 これは, 交点付近で誤って他の白線のエッジを選ばないよ うにするためである。

駐車判定を正確に行うには, エッジ画像で白線のエッジ が現れる部分だけを, 正確に, 白線領域として登録する必 要がある。しかし, 空車画像における白画素は, 取り込ん だ駐車場の画像を 2 值化し, 統計処理によって作成した画 像であるため, 実際の白線のエッジと完全に一致している わけではない。そこで, 白線領域を以下の手順で決定する。

(1) 複数枚の駐車場画像を取り込み, それぞれをエッジ画 像に変換する。

（2）分割された線分のそれぞれについて,

（ア）線分から上下（線分が水平に近い場合）または左 右 (垂直に近い場合)に 3 ピクセルずつずらして, 矩形領域を作る。

（亿）（ア）の領域に含まれる全ての画素について, 入力 画像の半数以上にエッジがあるときには, その画 素をその線分に対する白線領域として登録する。

〈6·3〉領域の対応付け ある区画に停まった車両は カメラから遠い位置にある白線を隠す。図 2 から 8 に示し たカメラ配置では, 駐車区画の直上の白線が隠される。そ こで, カメラの向きと白線・駐車区画の位置から遮蔽され る白線領域を予測し, 駐車区画に対応付ける。

$\langle 5 \cdot 2\rangle$ 節の白線の補完で用いたカメラ位置を利用して, 各駐車区画がカメラから離れる方向を求める。この方向を 画面に投影し, 画像上でカメラから遠ざかる方向を求める。 この方向で, 駐車領域から一定距離以内で最も近い白線領 域 1 つをその駐車領域に対応付ける。

対応付けられた白線領域には, 駐車領域の ID から 100 を 引いた值を ID として与える。このため, 記録できる駐車区 


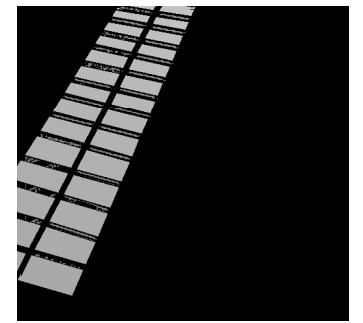

(a) Automatically generated template image

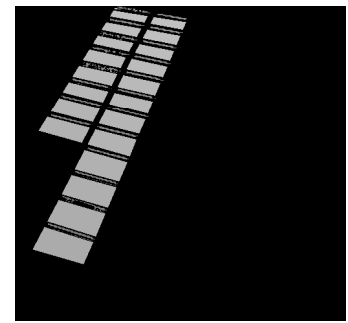

(b) Removing wrong parking divisions from (a)
図 9 作成されたテンプレート画像

Fig. 9. A synthesized template image.

画数は最大で 100 となるが，通常はこれで十分である。テ ンプレート画像では，その白線領域に含まれる全ての画素 にこの ID を記録する。

こうして作成したテンプレート画像を図 9(a)に示す。ただ し, 先行研究 ${ }^{(8)}$ では普通車しか検出対象としていないので, 左側の普通車の区画しか含まれていない。

周期性を使って補完した結果，ゼブラゾーンにも駐車区 画が設定されてしまった。このような誤りを完全に防ぐこ とは難しいので，不都合がある場合には人間が修正する。 この例では，左下 4 区画を消去している。駐車区画のIDを 指定して駐車領域とそれに対応する白線領域を消去するイ ンターフェースを作成しているので，簡単に消去できる。

縦 $512 \times$ 横 640 画素の 6 枚の画像を入力してからテンプレ 一ト画像が作成されるまでの時間は, Pentium4 2.6GHz CPU, 256MB メモリ，Windows XP の環境下で，約 20 秒であった。 画像中の駐車区画の数やノイズの程度により処理時間は増 減するが，概ねこの程度である。入力画像を選択する時間 や余分な区画を取り除く時間が必要あるが，それを加えて も数分で済む。これまでは手作業で 1〜2 時間かかっていた ことと比べると，大幅な時間短縮になっている。人が行う 作業も, 先行手法ではペイントツールを使って画像を修正 する必要があったが，本研究の手法では，画像を選んだり， 余分な駐車領域を指定したりするだけでよい，このため， 労力の点でもはるかに小さくなっている。

\section{7. 検証実験}

東名高速道路上郷サービスエリアの画像 11 枚を用いて実 験を行った。これらの画像は，同一の監視カメラで，1日の 間に時間を空けて撮影されている。時刻により認識率が変 化するため, 昼間, 夜間の両方を含む画像で実験する。そ れぞれの画像には20の駐車区画が写っているため,のべ220 区画の駐車を判定した。

図 10 では，白線領域のエッジ点の割合を横軸に，駐車領 域のエッジ点の割合を縦軸にとって，それぞれの駐車領域 をプロットしている。これらの割合は, 自動作成したテン プレートを使って計算した。図中の菱形（黒色，白抜きと も）は実際に空車だった駐車区画を，正方形は実際に車両 があった区画を示している。

2 章で述べたように，白線領域のエッジの割合が閾值未

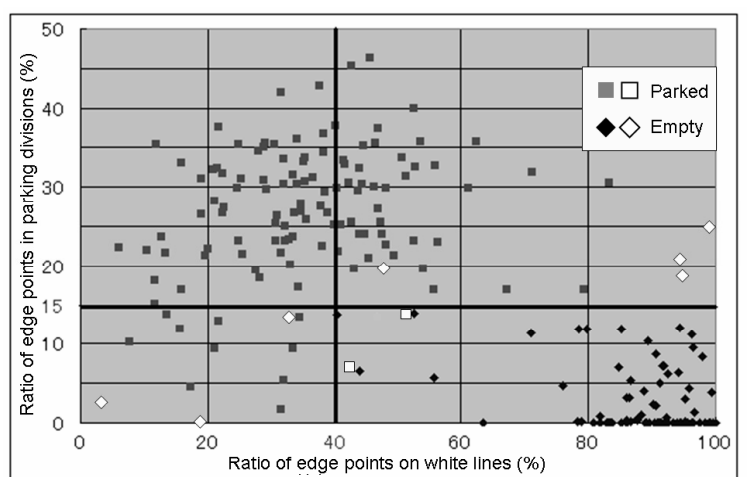

図 10 車両検出実験の結果

Fig. 10. The experimental result of car detection.

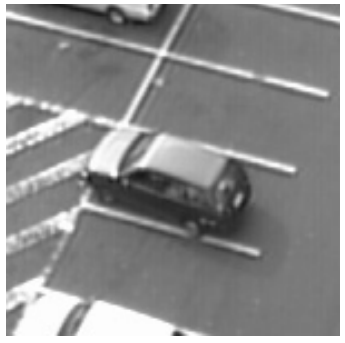

(a) Input image

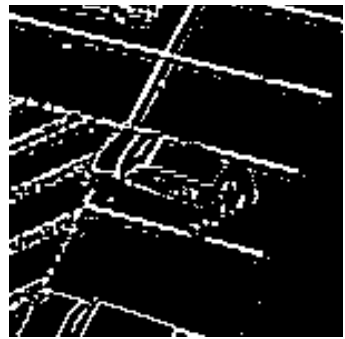

(b) Edge image of (a)
図11 誤って空車と判定された駐車区画

Fig. 11. A parking division which is wrongly judged as empty.

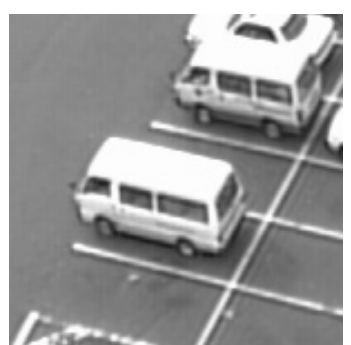

(a) Input image

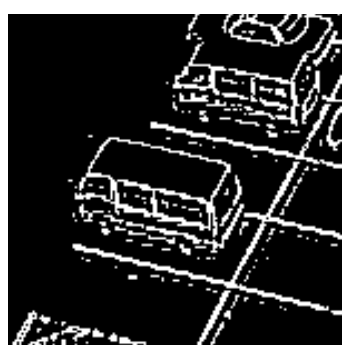

(b) Edge image of (a)
図 12 誤って駐車と判定された駐車区画

Fig. 12. A parking division where a car was wrongly detected.

満，または，駐車領域のエッジの割合が閾値以上の場合に 駐車車両ありと判定される。今回の実験では, 検出精度が 最も高くなるように, 白線領域の閾值を $40 \%$ に, 駐車領域 の閾值を $15 \%$ に設定している。図 10 の太線はそれぞれの闇 值を示している。判定プログラムでは, 右下の象限に入っ た区画が空車と判定され，他は駐車車両ありと判定される。 したがって，白抜きの菱形で表示した 7 区画が誤って駐車 と判定され, 白抜きの正方形で表示した 2 区画が誤って空 車と判定されている。

図 11 に誤って空車と判定された例を示す。この車は白線 をほとんど隠していない。しかも, 色が黒いため駐車領域 のエッジが少ない。このため, 空車と判定されてしまった。 車が無いのに駐車と判定されるのは, 図 12 に示すように, 
背の高い車が隣の区画にはみ出して写っている場合であ る。また，手前の白線を隠すように，横にはみ出して停ま っている車がある場合には, 手前の区画にも車両があると 誤って判定されてしまう。

この実験では 220 区画中 211 区画が正しく認識できたの で，自動生成したテンプレート画像を使った検出精度は 96.4\%となった。先行研究では, 手作業で作成したテンプレ ートを使って行って同じ実験をしているが，このときの検 出精度は約 98\%であった ${ }^{(8)}$ 。自動生成テンプレートでは認識 率が若干下がったが，駐車場の混雑状況を判定する目的に は十分な精度である。他のカメラの画像でも, 同様の実験 を行っているが，おおむね同じ程度の精度となっている。

認識率低下の原因は, 自動生成したテンプレートの白線 領域に, 統計処理で発生したノイズが載っていたためであ る。今回の実験では，完全な空車画像が作成できなかった ため,ノイズの影響が大きくなってしまった。

\section{8. むすび}

白線の遮蔽を利用した駐車車両の判定処理に使うテンプ レート画像を自動作成する手法を提案した。提案手法の特 徵は, 統計処理による空車画像の作成, 消失点を使った平 行線の検出, 白線の規則性を用いた伸張と検出漏れの補完 である。

提案手法で作成したテンプレート画像を使って車両の認 識実験を行ったところ, 約 96\%の精度で車両を検出できた。 認識精度は，手作業で作った場合に比べると若干低いが， 駐車状況を評価するには十分な值である。先行研究ではテ ンプレート画像の作成に 1 枚あたり 1〜2 時間の作業を必要 としていたが, 提案手法ではほとんど人手を介さずにテン プレートを作成できた。

今後は，ゼブラゾーンにできた誤った駐車領域を除去す る処理を追加する。また, 多くの駐車場で実験を行い, テ ンプレート画像の性能を評価する。

(平成 18 年 3 月 27 日受付, 平成 18 年 9 月 12 日再受付)

\section{文献}

(1) ITS Homepage of Ministry of Load, Infrastructure and Transport: 国土交通省道路局 ITS ホームページ： http://www.mlit.go.jp/road/ITS/j-html/

(2) Homepage of Automobile inspection and Registration Association: 自動車検査登録協会ホームページ: http://www.aira.or.jp/

( 3 ) T. Hasegawa and S. Ozawa : "Counting cars by tracking of object in the outdoor parking lot”, T. IEICE, Vol.J76-D2, No.7, pp.1390-1398 (1993-7) (in Japanese)

長谷川為春・小沢慎治 :「移動物体追跡を利用した屋外駐車場におけ る車両計数」, 信学論, J76-D2, 7, pp.1390-1398 (1993-7)

(4) E. Maeda, Y. Takahashi, and K. Ishii : "Robust object detection under various environmental conditions", T. IEICE, Vol.J74-D2, No.12, pp.1731-1740 (1994-12) (in Japanese)

前田英作・高橋裕子・石井健一郎：「環境変動にロバストな物体有無 判定法」，信学論, J74-D2, 12, pp.1731-1740 (1994-12)

( 5 ) K. Yamada and M. Mizuno : "A parking vehicle detection method using image segmentation”, T. IEICE, Vol.J82-D2, No.12, pp.2316-2324 (1999-12) (in Japanese)

山田啓一・水野守倫：「領域分割を用いた画像による駐車車両検出 法」, 信学論, J82-D2, 12, pp.2316-2324 (1999-12)

(6) C. Hsu, T. Tanaka, N. Sugie, and K. Ueda : "Detection of Vehicles in a Parking Lot by Image Processing", Proc. MVA2002 IAPR Workshop on Vision Applications, pp.475-478 (2002-12)

（7）川上 肇・土屋充央・池田 徹・田島譲二：「駐車車両からの駐車 状況検出」, 計測自動制御学会, 第 14 回パターン計測部会研究会, pp.1-7 (1991-1)

(8) K. Umino, T. Tanaka, and N. Sugie : "Detection of Vehicles in a Parking Lot by Image Processing", Proc. 11th World Congress on ITS, paper number 3205, Nagoya, Japan (2004-10)

(9) H. Tamura : "Computer Image Processing", Ohmsha, Tokyo (2002) (in Japanese) 田村秀行 :「コンピュータ画像処理」, オーム社 (2002)

(10) J. Sato : "Computer Vision", Corona Publishing, Tokyo (1999) (in Japanese)

佐藤 淳:「コンピュータビジョンー視覚の幾何学ー」, コロナ社 (1999)

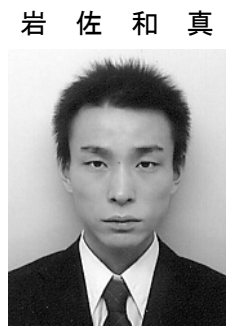

（非会員） 1982 年生。 2004 年 3 月名城大学理 工学部電気電子工学科卒業, 2006 年 3 月同大学 大学院理工学研究科情報科学専攻修士課程修 了, (株)ユーフィット勤務, 現在に至る。画像 処理に関する研究に従事。

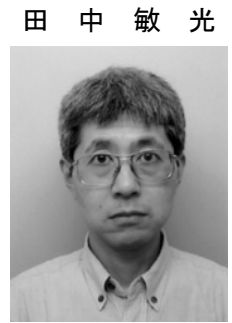

佐 川 雄 二

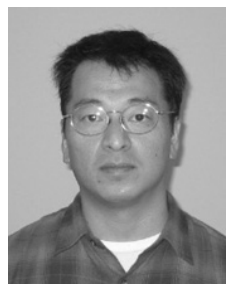

杉江昇

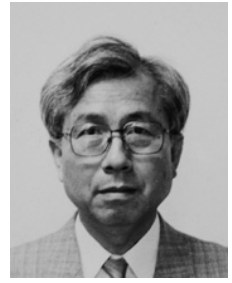

（非会員） 1959 年生。1984 年同大学大学院情 報工学専攻博士（前期）修了。同年 NTT 入社。 1994 年名古屋大学大型計算機センタ一助教授。 2000 年 4 月より名城大学理工学部情報科学科 (現情報工学科) 教授。コンピュータグラフィ ックスの研究・教育に従事。工学博士。1990 年信学会篠原記念学術奨励賞。1991 年情報処理 学会論文賞受賞。

(会員) 1961 年生。1987 年名古屋大学大学院 情報工学専攻前期過程修了。同年（株）日立製 作所入社。1992 年名古屋大学大学院情報工学専 攻後期過程単位取得退学。同年同大助手。同講 師を経て, 2000 年名城大学理工学部講師, 2003 年同助教授。現在に至る。自然言語処理の研 究・教育に従事。工学博士。

（非正員） 1932 年生。1960 年名古屋大学工学 部電気学科卒業。同年通産省電総研入所。1962 〜1964 年カナダ・マギル大学客員研究員。1978 年名古屋大学・工・情報工学専攻教授, 1994 年名城大 - 理工・電気電子工学科教授, 2000 年同情報科学科教授。名古屋大学名誉教授。信 学会フェロー。バイオニクス, コンピュータビ ジョン, 自然言語などの研究に従事。工学博士。 